\title{
Analyzing Millennial Generation Awareness on Nationalism During Covid-19 Pandemic
}

\author{
Sab Fitri Nur Hayati ${ }^{1}$, Moses Glorino Rumambo Pandin ${ }^{2}$ \\ ${ }^{1}$ Faculty of Nursing, Airlangga University Surabaya \\ ${ }^{2}$ Faculty of Humanities, Airlangga University Surabaya \\ sab.fitri.nur-2020@,fkp.unair.ac.id; moses.glorino@fib.unair.ac.id
}

\begin{abstract}
Background: In the current era of globalization, the Indonesian government's problem today is the weakening of nationalism and patriotism among the millennial generation. The large number of foreign cultures that have entered Indonesia has caused a sense of nationalism and patriotism. In addition, Indonesia is also facing the problem of spreading the Covid-19 virus. During the pandemic, various policies set by the government received protests from some circles because they felt their freedom was restricted. Therefore, the awareness of millennial generation nationalism is needed, especially during the Covid-19 pandemic like today. This research aims to make millennials aware of nationalism sense, which mainly to prevent the spread of Covid-19. This research is used to answer the questions of what the problems that arise due to the waning of the spirit of nationalism during the pandemic are? and what efforts should be made to maintain the spirit of nationalism? Methods: This research is a qualitative study using the literature review method. The articles used are research published in 2019 to 2021 in Google Scholar, with keywords that match the topic of millennial generation nationalism in the Covid-19 pandemic. Results and Discussion: The results of the study found that the spirit of Indonesian nationalism during the Covid-19 pandemic was decreasing. The decline in the sense of nationalism is due to several government policies that impact the psychology of society and the Indonesian economy. As a result, society, particularly the millennial generation, must play a role in breaking the chain of the Covid-19 virus's propagation by following the government's health standards. Conclusion: The government and society need to work together to understand nationalism in the millennial generation, especially in dealing with problems caused by the Covid-19 pandemic. Based on this, various efforts need to be made to foster the spirit of nationalism and overcome the Covid-19 pandemic. So that later, it can produce a generation that upholds the value of nationalism in everyday life.
\end{abstract}

Keywords: nationalism, the millennial generation, covid-19 


\section{Introduction}

Indonesia is a country with race, religion, language, and religious customs (1). As the largest archipelagic country with 17,504 islands, Indonesia also has a wealth of natural resources(2). As a pluralistic country, Indonesia cannot avoid the challenges posed by globalization. The Indonesian nation must stick to Pancasila to not lose its identity and continue advancing towards its goals(3). Pancasila must be a guideline for life in society, nation, and state.

In the current era of globalization, one of the problems facing the Indonesian nation today is the lack of nationalism and patriotism among the millennial generation(3). The large number of foreign cultural influences entering Indonesia has caused a sense of nationalism and patriotism. Millennials believe that foreign cultures are more modern, and not a few people are following Western lifestyles. They are proud to use foreign products and forget about products made by the nation's children. In this case, nationalism is needed to maintain the integrity of the Unitary State of the Republic of Indonesia.

Apart from weakening the spirit of nationalism, Indonesia is also facing a virus outbreak known as Covid-19. As we know, the Covid-19 virus has hit various countries in the world. The Covid-19 virus, which originated in the Chinese city of Wuhan, is spreading rapidly as people pick it up as they travel from one location to another. The virus is brutal to stop and has caused hundreds of deaths across the country. In Indonesia alone, positive cases of Covid-19 are increasing every day. Even medical personnel are getting more and more difficult because there is a surge in patients who are not proportional to the number of medical personnel(4).

During the Covid-19 pandemic, the spirit of Indonesian nationalism was facing a tough test. The government, which implements a health protocol policy such as carrying out all activities from home, has received protests from several circles. They feel unprepared and even violate appeals from the government because they think their freedom is restricted. As a result of society's negative stigma, this has led to divisions and can even lead to turmoil in the country's stability(5). As we know, the spread of Covid-19 is getting wider every day. Many people ignore the appeal from the government and cause the space of Covid-19 to become increasingly out of control. Therefore, we need to have awareness within ourselves to help the government in overcoming this pandemic.

People expect the younger generation to become the motor of development(3). The future of the Indonesian nation depends very much on the way the younger age behaves and acts. 
However, if the spirit of nationalism of the millennial generation has faded, the nation's future is also very worrying. As the nation's next-generation, we must act decisively and reject foreign cultures that can harm the country's morals. Therefore, Pancasila is used to act and speak to realize national development by the nation's goals.

The spirit of nationalism is very much needed by society to have no division in the Indonesian nation. Together with the government, the community must make various efforts to maintain the spirit of nationalism of the younger generation to fade away. Based on this background, the authors want to examine several problems caused by the decreasing of nationalism values among younger generation during the pandemic, which followed by several research questions: What are the issues arising from the waning nature of nationalism during the pandemic?, and What efforts should be made to maintain the spirit of nationalism?.

\section{Method}

The methods used in this research is a qualitative study using the literature review method. A literature review describes theories, findings, and other research articles obtained from reference materials to be used as the basis for research activities(6). The literature review contains reviews, summaries, and the author's thoughts on several studies according to the topics discussed.

The object of study in this article is the spirit of Indonesian nationalism during the Covid19 pandemic. In contrast, the subject of the study is the millennial generation or the youth of the Indonesian nation. The type of data used in this article is secondary data obtained from several sources to support the research. The data used as research sources are articles in Google Scholar relating to nationalism during the Covid-19 pandemic.

The article used is the latest research published in google scholar from 2019 to 2021. The literature focused on the keywords: "Nationalism", "Millennial Generation", and "Covid-19", and also use Boolean Operators ( AND, OR or NOT)

Table 1. Keyword Search for Literature Review

Nationalism for

National Spirit of
Millennial Generation

Millennial Generation
Covid-19
OR
OR
Corona outbreak 
Patriotism for

the Young Generation

CoronaVirus

\begin{tabular}{lll}
\hline AND & OR & OR \\
\hline Nationalism & Youth & Pandemic Covid-19 \\
\hline
\end{tabular}

In the first stage, the author looks for several articles with similarities in their research, whether results, interventions, methods, or others(6). Furthermore, the authors select the data based on the suitability of the research theme. So that ten articles were obtained that matched the theme of nationalism during the Covid-19 pandemic. The author then constructed the ten papers and aggregated the data to analyze and interpret them for this study. The articles collected and were determined to meet several criteria:

Table 2. Inclusion and Exclusion Criteria

\begin{tabular}{lll}
\hline \multicolumn{1}{c}{ Criteria } & \multicolumn{1}{c}{ Inclusion } & \multicolumn{1}{c}{ Exclusion of } \\
\hline Population & $\begin{array}{l}\text { Studies of nationalism values } \\
\text { among the millennial } \\
\text { generation during Covid }\end{array}$ & $\begin{array}{l}\text { The studies are not about } \\
\text { nationalism values among } \\
\text { the millennial generation }\end{array}$ \\
\hline pandemic-19 & during pandemic Covid-19 \\
\hline Results & No comparison & - \\
\hline The article contains issues & The articles do not contain \\
& about the weakening of the & the weakening of the \\
& nationalism values among & nationalism values among \\
& the Millennial generation & the millennial generation \\
& during the Covid-19 & during the Covid-19 \\
& pandemic and the efforts that & pandemic and the efforts that \\
& must be made to restore the & must be made to restore the \\
& spirit of millennial & spirit of millennial \\
generation nationalism. & generation nationalism. \\
\hline
\end{tabular}




\begin{tabular}{lll}
$\begin{array}{l}\text { Types of research and types } \\
\text { of publication }\end{array}$ & $\begin{array}{l}\text { Qualitative research } \\
\text { published in google scholar }\end{array}$ & No exceptions \\
\hline Year of publication & $2019-2021$ & Under 2019 \\
\hline Bahasa & Indonesian & Indonesian addition \\
\hline
\end{tabular}

\section{Results}

Based on the method used, the study results show that the waning of the nationalist spirit of the millennial generation stems from internal factors such as the state of the surrounding environment and external factors originating from poor government performance(3). The family environment and the lack of education obtained by adolescents can cause nationalism to fade. In addition, the public's disenchantment with the government's work that does not provide justice to the community is also one of the causes of the weakening of the spirit of nationalism. This influence does not directly affect nationalism. But overall, the millennial generation's sense of nationalism will decrease or even disappear(7).

The weakening of nationalism also occurs in the religious aspect, which is shown by identity politics. The emergence of identity politics is usually synonymous with the religion, ethnicity and politics of the majority group to eliminate minority groups considered deviant(8). Therefore, the government needs to make efforts to prevent divisions caused by identity politics. The government and society must work together to restore the spirit of nationalism in the Indonesian nation.

During the Covid-19 pandemic, the nationalism of the Indonesian nation got worse because several government policies had an impact on the psychological side of the community. The emergence of Covid-19 patients caused panic buying in the community. Not only that, many parties deliberately hoard masks to resell at high prices(9). Even though the community needs masks to avoid the spread of the coronavirus. The amount of news about Covid-19 makes people more sensitive and easily influenced(10). The emergence of problems hitting the community during the Covid-19 pandemic is due to a lack of socialization to the public about new government policies such as lockdown activities(5). Government policies classified as indecisive make people increasingly indifferent to the current condition of the Indonesian people. 
Furthermore, the economy sectors in Indonesia has decreasing due to lockdown's policy, which resulted the termination of all sectors. The cessation of the wheels of the Indonesian economy has caused millions of people to lose their jobs and impact increasing unemployment. Some of the harmful effects of unemployment are poverty, hunger, looting, and crime(11). This will get worse if the government does not take immediate action to address it.

Even the education sector has also been badly affected by the Covid-19 pandemic. The government issued a circular regarding learning from home, and students were forced to use distance learning patterns(12). The implementation of learning from home makes the character of the millennial generation decrease so that it is necessary to strengthen character education by instilling religious, honest, tolerant, disciplined, creative, independent, and hard-working attitudes.

To overcome this, the role of the community, especially the millennial generation, is needed to break the chain of spreading the Covid-19 virus. The millennial generation needs to become a strategic political force to realize the goals of the New Normal policy. The millennial generation needs to adapt in carrying out this role. The strategy in breaking the chain of the spread of Covid-19 can be done in groups or individually and can be directly or online(13).

Public awareness to comply with health protocols is necessary so that the spread of the Covid-19 virus does not apply. The community needs to have the spirit of cooperation in dealing with the coronavirus according to the government's strategy. The public expected to obey the existing appeals and participate in preventing the spread of this coronavirus(14). Therefore, the spirit of cooperation is needed by many parties so that they can trust each other and be able to be positive in dealing with the Covid-19 pandemic.

\section{Discussion}

\section{Nationalism Awareness in Social Life}

Along with the entry of western culture the spirit of Indonesian nationalism is gradually fading, especially among the millennial generation. Globalization can easily change all human activities, including attitudes and personalities(7). The rapid development of technology has also weakened the sense of nationalism among the younger generation. If the technology is utilized optimally, we will get valuable results, but it also has detrimental effects when abused. Based on the explanation above, we can see that technological developments do not only bring good 
impacts. On the contrary, even the harmful effects of technological developments are more common, especially among the millennial generation.

At present, more and more millennial generations are losing a sense of nationalism in their lives(15). One example is the occurrence of brawls between adolescents. Adolescents lack the attitude to achieve their ideals to advance the Indonesian nation. This has come from their educational background. So far, Indonesian education has paid less attention to emotional aspects and spiritual wisdom. Society believes that people who can memorize lots of formulas, learn foreign languages, and answer quickly are smart.

In addition, education in Indonesia faces challenges that stem from the character of the millennial generation(16). They tend to be selfish and unruly. This is because they are misusing technology, such as playing online games, until they lose track of time. This phenomenon does not only occur in big cities. Many youths in the village also like to play online games rather than more valuable things. Therefore, education in Indonesia must be addressed starting from the basic level to create a sense of nationalism among the millennial generation.

In religious life, the relationship between religion and the state in political dynamics does not always show a harmonious relationship. This is because the world view considers religion and state as two objects that cannot be reconciled. Religion emphasizes aspects of morality, while the state is concerned with power in everyday life. One example of the disharmony between religion and state is formed in identity politics(8). The emergence of identity politics is synonymous with faith and political ideology, for example, in the 2019 Election, which is very thick with identity politics.

In the 2019 presidential election, the two candidate pairs tried to win Muslim voters' hearts who reached around 160 million people. Candidate pair number 1, Joko Widodo, chose $\mathrm{KH}$ Ma'ruf Amin as his running mate(8). Ma'ruf Amin is a well-known cleric with his position as chairman of the MUI and Rais Aam PBNU. Meanwhile, candidate pair number 2, Prabowo Subianto, connects with FPI and Ijtima Ulama to seek support from Muslim voters.

As can be seen, religion plays a vital role in building human civilization, including building social relations in state life(8). However, with the existence of Pancasila, which is the hallmark of the Indonesian nation, we have grown to become a democratic country. Indonesia is not an Islamic country, even though the majority of the population is Muslim. With Pancasila, all 
the differences in Indonesia can be unified so that the community can uphold the principles of unity and integrity.

The waning spirit of millennial generation nationalism comes from the influence of Western culture and comes from people's attitudes towards the environment around them. The simplest things, such as upbringing from the family, can also affect the loss of the spirit of nationalism of the younger generation(3). Apart from the family environment, the government's deteriorating performance made people feel disappointed and violated government regulations. The government has always made the values of justice and humanity a mere discourse. Even many high officials commit corruption for their gain. This, of course, makes people no longer believe in the performance of the government.

The flow of globalization, which results in the loss of love for domestic products, is one of the external causes of waning the spirit of nationalism in the Indonesian nation(3). The large number of foreign products circulating in the Indonesian market makes the younger generation prefer to use them rather than domestic products. They feel that domestic products look left behind and lack quality. In addition, the liberalism that has entered Indonesia has caused youths to have high individualistic attitudes even though this attitude is not by the principle of cooperation in Pancasila.

\section{Awareness of Nationalism during the Covid-19 Pandemic During the Covid-19}

The findings of this research data show that during the Covid-19 pandemic, various problems arise that can weaken the nationalism of the Indonesian nation(5). The emergence of SARA is widely circulating on social media, has created a potential for division because the public is quickly consumed by hoax news without looking for the truth. In addition, the lack of socialization about the government's new policies left people with insufficient knowledge to live their lives during the pandemic. Covid-19, which has an impact on the economic sector, adds to public unrest.

At the beginning of the Covid-19 outbreak in Indonesia, several parties hoarded masks which increased mask prices(9). When masks are expensive, they sell masks at a double profit. This is very detrimental to the community, especially the middle to a lower class. People are forced to use cheaper cloth masks as personal protective equipment. However, cloth masks do 
not meet mask standards, so they are not optimal to protect the body from exposure to the Covid19 virus.

After the policy was enacted lockdown, there was an increase in the poverty rate because the world of work stopped utterly. The policy has lockdown increased the unemployment rate, which is getting higher. If the government does not immediately deal with this, other problems will arise, such as hunger, theft, robbery, to crime(11). A person will do everything he can to fulfill his needs, even in the wrong way. This will undoubtedly have an impact on the weakening of the spirit of nationalism in society.

The covid-19 pandemic has also hurt a psychological aspect(10). The majority of people feel afraid if they are attacked by corona. The emergence of the first positive patient in Indonesia led toled panic buying, in which buying daily necessities such as masks and hand sanitizers is excessive. For positive corona patients, of course, they feel stress because they have to undergo independent isolation and be separated from their families. Over time, the efforts made by the government have made people feel calm while experiencing activities during the pandemic. To control this virus's spread, the public needs to participate in obeying the government's appeal(14). Millennials can participate by socializing about the dangers of the Covid-19 pandemic, distributing social assistance to people in need, and providing a place to wash their hands outside the home(13).

The various impacts of Covid-19 have been able to diminish the spirit of nationalism for the millennial generation. The government needs to restore the confidence of nationalism to the millennial generation because they hope for the nation's future. One of the efforts that can be done is through character education. The role of society is also needed to shape the character of the millennial generation(12). The functions of parents and teachers are expected to shape the character values of youth for the better.

So those various efforts are needed to regenerate the spirit of nationalism of the millennial generation. This effort is the government's responsibility and requires an active role in the community(7). For example, parents need to instill a sense of love for domestic products from the part of the family. In the educational aspect, it is necessary to have character education starting from the elementary school level. The millennial generation does not readily absorb negative things that can threaten national security. Character education is the primary key in forming a millennial generation who has a high sense of nationalism. 


\section{Conclusion}

The increasingly widespread Covid-19 pandemic makes people feel anxious, which affects psychological aspects. Government policies that require people to always at home have also exacerbated the psychological condition of the millennial generation. Those who tend to be free were trying to carry out activities at home for one year. From a psychological aspect, Covid19 also causes various problems that can weaken the nationalism of the millennial generation. Some of these problems include the emergence of hoax news about the corona, panic buying, hoarding of masks, and criminal acts due to the increasing unemployment rate in Indonesia. Therefore, the government needs to make various efforts to regenerate the spirit of millennial generation nationalism. One of them is requiring character education starting from the elementary school level so that the millennial generation does not readily absorb negative things that can threaten national security.

The concept of nationalism, or nationalism of a nation, is having a sense of awareness and enthusiasm for the love of one's homeland, which manifests itself in society in attitudes and behaviours, regardless of differences. It is the colour difference that must balance in an equation. Bhinneka Tunggal Ika plays an essential role in achieving this. The development of multiculturalism absolutely must be formed and implanted in a pluralistic society. With this research, it is hoped that the millennial generation will maintain the spirit of nationalism and make good use of technological developments for the progress of the Indonesian nation. Based on the study results, the literature review method is suitable to examine the theme of the waning spirit of the millennial generation of nationalism during the Covid-19 pandemic. However, the research results only explain general terms, so quantitative research is needed to obtain more detailed results.

\section{References:}

1. Yayuk Hidayah, Nufikha Ulfah S. Implementasi Pancasila di Kalangan PNS Generasi Milenial dalam Menghadapi Pandemi Covid-19. J Pancasila Dan Kewarganegaraan. 2019;4(2):22-33.

2. Rachmawati SS. Memperkuat Kesadaran Bela Negara Di Tengah Pandemi Covid-19 (Strengthening the awareness of defense country in the middle of the Covid-19 pandemic). SSRN Electron J. 2020;1-6.

3. Lestari EY, Janah M, Wardanai PK. Menumbuhkan Kesadaran Nasionalisme Generasi 
Muda Di Era Globalisasi Melalui Penerapan Nilai-Nilai Pancasila. Adil Indones J. 2019;1(1):27.

4. Boer KM, Pratiwi MR, Muna N. Analisis Framing Pemberitaan Generasi Milenial dan Pemerintah Terkait Covid-19 di Media Online. Commun J Ilmu Komun. 2020;4(1):85104.

5. Jayendra PS. Nasionalisme Dalam Bayang-Bayang Pandemi Covid-19: Sebuah Refleksi Peran Public Relations Dalam Penguatan Nilai-Nilai Kebangsaan. 2021; Available from: https://osf.io/preprints/tdq7v/

6. Ermawati N. Buku Ajar Mata Kuliah Metodologi Riset "Penelitian Data Sekunder". Politek Kesehat RS Dr Soepraoen Malang. 2020;

7. S. Widiyono. Pengembangan Nasionalisme Generasi Muda di Era Globalisasi. J Popul. 2019;7(1):12-21.

8. Pattimahu MA. Agama Dan Masa Depan Kebangsaan Indonesia. Dialektika. 2020;13(1):59-71.

9. Andika NPIP. Perlindungan Hukum Terhadap Konsumen Atas Melonjaknya Harga Masker Akibat Virus Covid-19. 2021;9(4):556-68.

10. Muara T, Prasetyo TB, Rahmat HK. Psikologi Masyarakat Indonesia Di Tengah Pandemi: Sebuah Studi Analisis Kondisi Psikologis Menghadapi Covid-19 Perspektif Comfort Zone Theory. Ristekdik J Bimbing dan Konseling. 2021;6(1):69.

11. PH L, Suwoso RH, Febrianto T, Kushindarto D, Aziz F. Dampak Pandemi Covid-19 Bagi Perekonomian Masyarakat Desa. Indones J Nurs Heal Sci. 2020;1(1):37-48.

12. Yoga Purandina IP, Astra Winaya IM. Pendidikan Karakter di Lingkungan Keluarga Selama Pembelajaran Jarak Jauh pada Masa Pandemi Covid-19. Cetta J Ilmu Pendidik. 2020;3(2):270-90.

13. Nanggala A. Peran Generasi Muda Dalam Era New Normal. Widya Wacana J Ilm [Internet]. 2020;(June). Available from: http://ejurnal.unisri.ac.id/index.php/widyawacana/article/view/3827

14. Mahardika MN, Trisiana A, Widyastuti A, Juhaena JS, Mea R, Kirani A. Strategi Pemerintah Dan Kepatuhan Masyarakat Dalam Mengatasi Wabah Covid-19 Berbasis Semangat Gotong Royong. J Glob Citiz. 2020;IX(1):39-50.

15. Hasanah U. Internalisasi Ideologi Pancasila Melalui Lagu Kebangsaan Untuk Mencegah Memudarnya Nasionalisme. J IKA PGSD (Ikatan Alumni PGSD) UNARS. 2020;8(2):440.

16. Barni M. Tantangan Pendidian di Era Milenial. J Transform. 2019;3(april):99-116.

17. Azzahra, S. S., Pandin, M., \& Pandin, M. (2021). The factors of bullying and character education on teenagers. April, 1-9. https://doi.org/10.20944/preprints202104.0102.v1

18. Khansas, A., Kumala, D., \& Pandin, M. (2021). Archipelago Insights as Efforts to Establish National Geostrategic Resilience: A Literature Review. Preprints, May. https://doi.org/10.20944/preprints202105.0154.v1

19. Munir, M., Glorino, M., Pandin, R., Mada, U. G., Trilogi, U., Airlangga, U., Airlangga, U., \& Java, S.-E. (2020). Human Resource Information System and Work Stress during COVID-19 Pandemic. December, 1-14. https://doi.org/10.20944/preprints202012.0469.v1

20. Wicahyanti, P. A., Rahim, N. A., Glorino, M., \& Pandin, R. (2021). The Awareness of Millennial Generation during Covid-19 Pandemic towards State Defense Character. May, 1-12. https://doi.org/10.20944/preprints202105.0122.v1 
Attachment

Table 3. Literature Results

\begin{tabular}{|c|c|c|}
\hline No & Citation & Findings \\
\hline 1 & (Jayendra, 2020) & $\begin{array}{l}\text { The problems experienced by the Indonesian people } \\
\text { during the pandemic were caused by a lack of } \\
\text { government policies and uncontrolled negative news } \\
\text { related to Covid-19. Also, the economy that did not } \\
\text { work and affect the raises of public unrest, including } \\
\text { a weakening of the spirit of nationalism. }\end{array}$ \\
\hline 2 & (Lestari et al., 2019) & $\begin{array}{l}\text { In the globalization era, several internal and external } \\
\text { causes are related to the waning of nationalism } \\
\text { among the millennial generation. Internal causes } \\
\text { come from the condition of the attitude and the } \\
\text { environment. Not only that, but the community } \\
\text { disappointment in the government's work also brings } \\
\text { several reasons for the weakening of the spirit of } \\
\text { nationalism. Meanwhile, external factors come from } \\
\text { technological developments and the entry of Western } \\
\text { culture, which quickly attracts the millennial } \\
\text { generation's attention. }\end{array}$ \\
\hline 3 & $\begin{array}{c}\text { (Purandina \& Winaya, } \\
\text { 2020) }\end{array}$ & $\begin{array}{l}\text { As a result of implementing the policy lockdown, all } \\
\text { sectors of human life have been suspended. This } \\
\text { causes the teaching and learning process to change } \\
\text { through online forums and be done from home. The } \\
\text { implementation of learning from home makes several } \\
\text { millennial generations feel bored, and often their } \\
\text { character deteriorates. For this reason, a collaboration } \\
\text { between teachers, parents and the surrounding } \\
\text { community is needed to develop children's character }\end{array}$ \\
\hline
\end{tabular}


values.

$4 \quad$ (Nanggala, 2020)

To overcome the problems caused by the Covid-19 pandemic, the role of the millennial generation is needed, especially in this New Normal era. Millennials can play a direct role, including by conducting socialization about the Covid-19 pandemic and how to deal with it, collecting and distributing social assistance, and providing a place to wash hands.

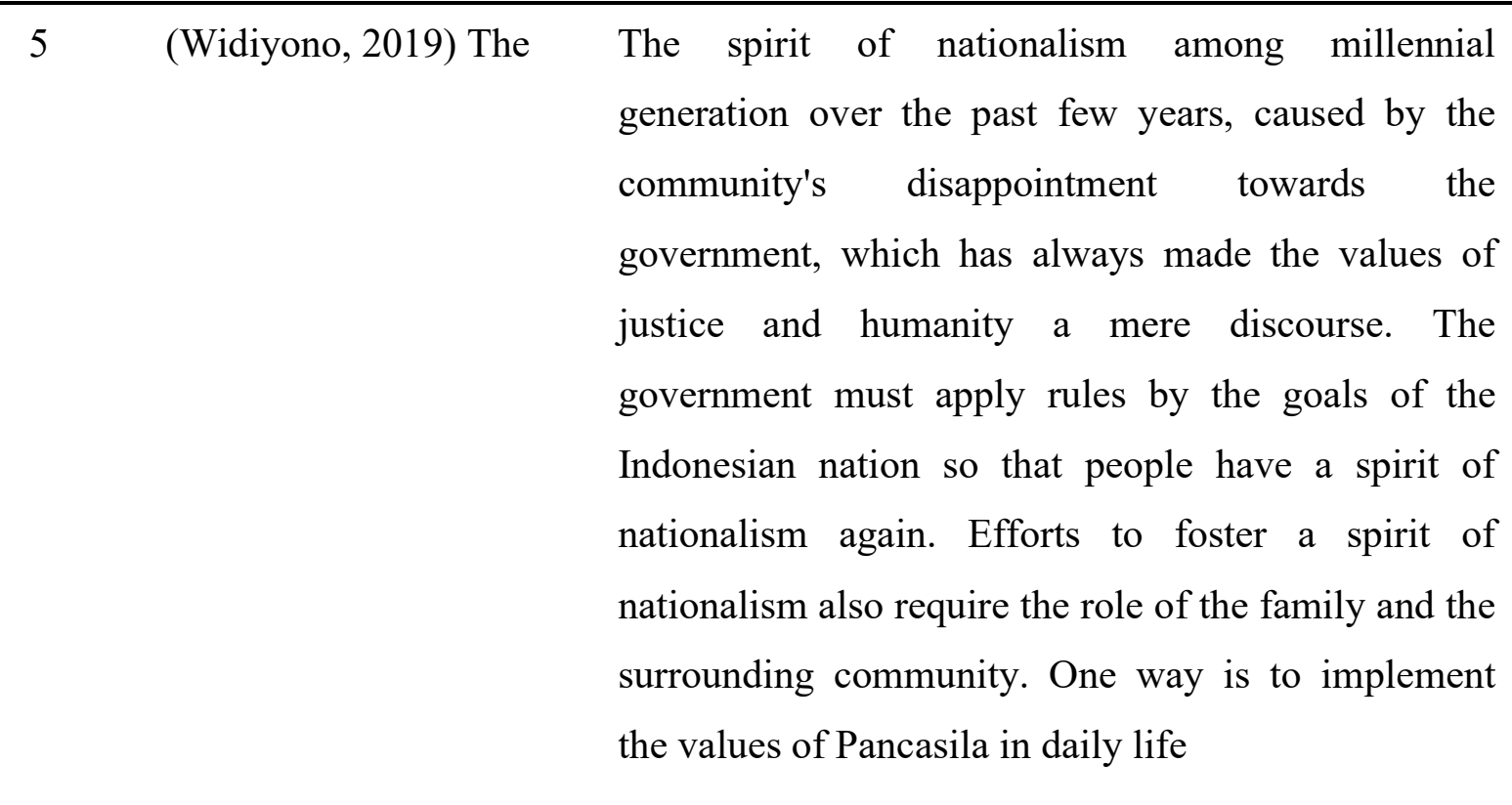

$6 \quad$ (Livana et al., 2020)

Covid-19 continues to spread further adds to the anxiety within the community. The government's application of social distancing has caused the economy to die and caused millions of people to lose their jobs. An increase in the unemployment rate can hurt human life. Some of the harmful effects due to many unemployed are poverty, hunger, looting, and crime. The government continues to strive to solve the problems caused by the Covid-19 pandemic from 
the economic, health, social, and other sectors.

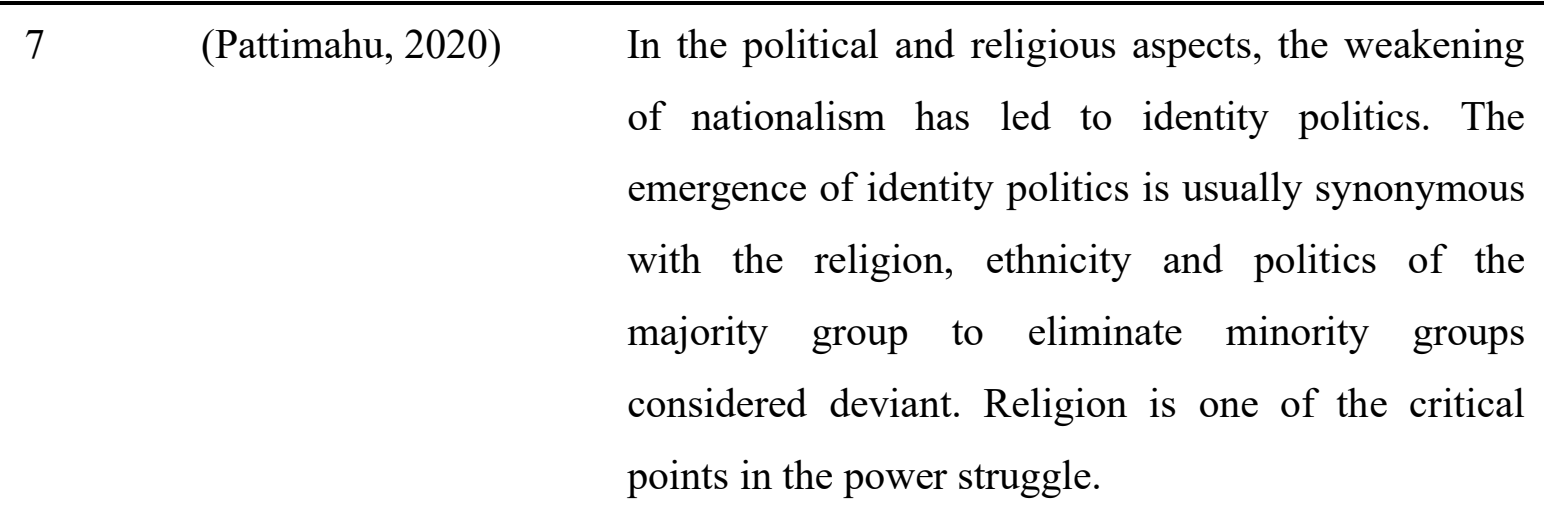

8 (Muara et al., 2021) The entry of the Covid-19 virus into Indonesia resulted in a panic buying for people who buy daily necessities such as masks and hand sanitizers in excess. Covid-19 also has an impact on the psychology of society, especially on positive patients with Covid-19. Some government policies such as lockdowns also interfere with people's mental health because they feel lonely while at home.

$9 \quad$ (Mahardika et al., 2020)

To break the chain of spreading Covid-19, the government has established a strategy of physical distancing and social restrictions in all regions. However, some communities do not comply with these rules because of their low-level knowledge about this pandemic. Public awareness is urgently needed so that there is no spike in positive cases of the corona. With the spirit of cooperation, the community was able to help the government and medical teams to break the chain of transmission of the Covid-19 outbreak. 
10 (Andika \& Priyanto, 2021) At the beginning of the spreads of Covid-19, many parties deliberately hoarded masks which increased mask prices. They get many personal benefits but are very detrimental to other societies. This forces people to look for other alternatives by using cloth masks as personal protective equipment. 